JMKSP (Jurnal Manajemen, Kepemimpinan, dan Supervisi Pendidikan)

Volume 6 Issue 2 (2021) Page 293-308

ISSN 2614-8021 (Online) 2548-7094 (Print)

\title{
Moral of Educational Leaders Based on Religious, Philosophy, Psychology and Sociology
}

\author{
Zainal Mukhtar ${ }^{1}$, Sofyan Sauri ${ }^{2}$, Faiz Karim Fatkhullah ${ }^{3}$, Iin Aryani ${ }^{4}$, Maria \\ Susana Yudianti ${ }^{5}$ \\ ${ }^{1}$ Universitas Pertahanan Republik Indonesia \\ 2,3,4,5 Universitas Islam Nusantara \\ Corresponding Author E-mail: zainal_muhtar90@yahoo.co.id
}

Received 25 May 2021; Revised 30 May 2021; Accepted 10 June 2021

\begin{abstract}
The existence of a leader greatly determines the progress and retreat of a country. This research uses descriptive qualitative research methods using literature study as data collection technique. Based on analysis data, the essence of leadership in the view of Islam can be defined as the trust which must be carried out well and held accountable not only in this world but also before Allah. According to Philosophy, a moral leader can do job based on deep way of thinking. According to Psychology, the leadership style of moral person influences the process of his daily life. According to Sociology, moral of educational leadership is greatly influenced by social conditions of society and its institutions. The application of leadership moral in educational institution is barometer of achieving success or not and has implication to the educational process. This research adds important value that must exist in an educational leader who is guided by the foundations of religion, philosophy, psychology and sociology.
\end{abstract}

Keyword: Moral, Educational Leaders, Religious, Philosophy, Psychology, Sociology 


\section{Introduction}

The existence of a leader determines the progress and retreat of a country. As a leader, he is required to have responsibilities, both responsibility to himself, as well as responsibility to his people. This responsibility is related to the morale of the leader. How a leader behaves in his daily life both towards himself and towards others must also reflect a moral leader.

Theoretically, leadership always exists in every environment, in large and small scups, and is always graded according to its social structure and environment. Everything is directed to achieve the goals expected by the group and organization in its environment. Not only the environment needs to be well managed, human social life also needs to be well managed. That is why quality human resources are needed. A resource that has the soul of a leader, at least to lead himself. Basically, the term leadership relates to the skills, competencies, and level of influence a person possesses. According to W Bennis (2021), All leaders have the capacity to create a compelling vision, one that takes people to a new place, and then to translate that vision into reality.

On the other hand, it can be said that a moral leader based on religion, philosophy, psychology and sociology will give birth to a just and wise leader. Therefore, there are some moral criteria of leadership that will be discussed below and how a moral leader in leading. In terms of how the morals of leadership based on religion, philosophy, psychology and sociology are mentioned is the leader that according to behavioral experts, such as how to delegate tasks, make decisions, communicate, and motivate subordinates. A leader must indeed have certain qualities/criteria to lead. Leader behavior is something that can be learned. So, someone who is trained with good and proper leadership morals will be able to be a trustworthy and imamate leader. The reason can certainly give new hope and optimism to anyone who pays attention to the world of education, especially those related to moral leaders in order to become qualified and Islamic leaders.

Based on the above description, this study takes the title "Moral of Educational Leaders based on religion, philosophy, psychology, and sociology". This study aims to analyze the moral of educational leaders based on religion, philosophy, psychology, and sociology. This research adds important value that must exist in an educational leader who is guided by the foundations of religion, philosophy, psychology and sociology. 


\section{Literature Review}

According to Newstrom (2011), Leadership is the process of influencing and supporting others to work enthusiastically towards achieving goals. This is not much different from the notion of leadership according to Robbins and Judge (2015) that leadership is the ability to influence a group in achieving goals.

From some explanations of leadership above, then leadership can be defined as a process of one's activities in influencing and mobilizing a group or a person to create a cooperation to achieve a predetermined goal. Leadership is often synonymous with leader, although the two words have different meanings. A leader is someone who is tasked with leading, while leadership is a talent or trait that a leader must possess.

Educational leadership is a process of giving influence to individuals and being able to mobilize those individuals in an organization or educational institution to achieve educational goals. The orientation of educational leadership is to make human resources within the scope of education can be coordinated to work optimally to achieve the specified goals. The role of leadership in this education can be seen from the following foundations:

a. Foundations of Religion

Leadership is very much needed when it comes to human activities that are done together. The existence of a leader aims to achieve success and effectiveness in performing an activity. Planning is needed to prepare newly trained leaders (Kartono, 2016). This effort becomes a very natural thing to do because every organization needs a top leader who manages the running of an organization's management. This has also been mentioned in the Qur'an (Q.S. Al-Baqarah: 247)

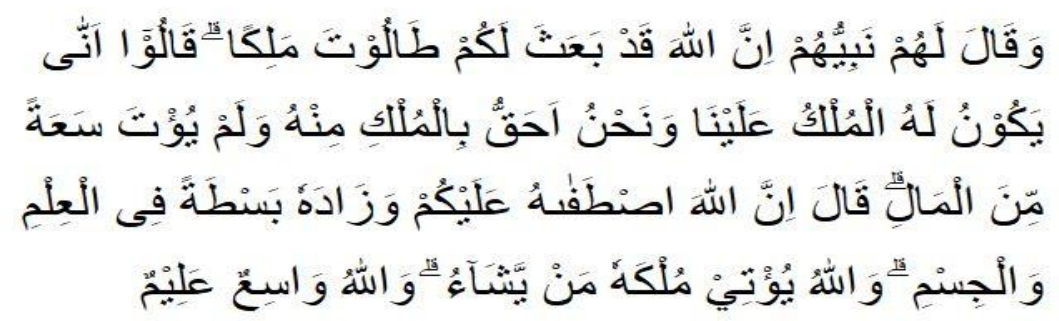

Meaning: "And their Prophet said to them, "Indeed, Allah has raised Talut to be your king." They replied, "How did Talut get the kingdom over us, when we are more entitled to the kingdom than him, and he was not given much 
wealth?" give His kingdom to whom He wills, and Allah is All-Embracing, AllKnowing”.

As for carrying out his duties, a leader needs some capital, among them is faith, knowledge and morals. It is this faith that will guide a leader to a belief that he is only a servant of Allah SWT. For science itself, in various forms, both forms of general, technical and social knowledge are also the main capital in leadership. A leader must have faith so that his heart is opened by God to obtain true and necessary knowledge. Later, this knowledge will help a leader run his organization and make decisions effectively. While morality here helps create a conducive environmental harmonization in an organization (Nugroho, 2016). By applying these three components, namely faith, knowledge, and morality, will provide blessings in the leader in the process of running the leadership of an organization in line with the teachings of Islam, namely Rahmatan lil'alamin.

The essence of leadership in Islam is a trust that must be carried out well and held accountable not only in this world, but in the hereafter before Allah SWT. So leadership is not a position or power that is worth being proud of because of its great responsibility. Therefore, leadership in organizations should be carried out professionally and proportionally. If not, then it violates the teachings of Allah SWT, as the Prophet SAW said,

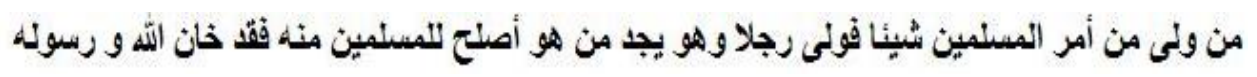

Meaning: "Whoever leads an affair of the Muslims and then he appoints someone when he finds a person who is more suitable for the interests of the Muslim Ummah than that person, then he has betrayed Allah and His Messenger". (HR. Hakim)

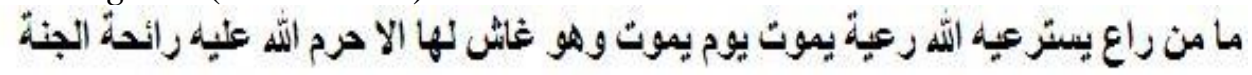

Meaning: "No leader is asked by Allah to lead the people who die while he is cheating on his people unless Allah forbids him to smell the smell of heaven". (HR. Muslim)

In the context of educational leadership, Imam Ghazali mentioned that a student is required to have a mentor who can remove his bad morals from within himself and replace it with good morals, he must also have a Sheikh who can educate and show him the way to Allah SWT. In his opinion, educational leadership must always have a goal to achieve the pleasure of God Almighty. There are four basic personal components of a leader in the world of 
education, among them are 1) he must have managerial skills that can make planning, organizing, implementation and evaluation can also be part of the people he leads; 2) having a trustworthy and responsible nature, the meaning is to be aware of his duties and must be carried out truly professionally; 3) be a role model or be a good example so that subordinates or members feel comfortable carrying out his orders; 4) Always carry out leadership that is bound by Islamic law, does not violate either his actions or words

\section{b. Philosophy Foundation}

According to Kneller in Helmawati (2016), educational philosophy is the application of philosophy in education. Philosophy is needed in education because the problems in the world of education are not only constrained by the implementation of education that is limited by experience but also there are broader, deeper and more complex problems that are not limited by experience or educational facts, and can be reached by science education.

1) Progressivism

In the world of education, the stream of progressivism has a great impact because this stream lays the foundations of independence and freedom to learners. To develop the talents and abilities of learners without experiencing obstacles that come from others. Seeing this, the flow of progressivism is the opposite of authoritarian education.

This stream sees learners dealing in particular with intellect and intelligence, this is shown by the fact that humans have advantages when paired with other living beings. This is because human beings have a dynamic nature with the support of their intelligence to face and solve problems faced. Thus, human beings are placed as intact biological beings and respect the dignity and worth of human beings as living performers (Barnadib dalam Kristiawan 2016).

The development of educational curriculum in the stream of progressivism emphasizes more on how to think, how to do, what to think and what to do, or can be interpreted, on this stream prioritizes and emphasizes on his method rather than his material. It aims to provide the ability to individuals in interacting with the ever-changing environment. By emphasizing the foundation of the philosophy of progressivism into the preparation of curriculum methodology can make the curriculum more flexible and adapt to change and better recognize the current conditions. 


\section{2) Constructivism}

Constructivism sees that in the process of teaching and learning, students or learners should be emphasized. Therefore, students are required to be active in developing knowledge, not teachers or others. This process requires the use of creativity and activity of students in order to make the student a critical person in analyzing something because here students are required to think and not just imitate. The process of teaching in this stream is not just transferring or transferring knowledge from people who already know (teachers) to people who do not know that is the student, but teaching is an activity to help a person to be able to form (construct) their own knowledge given through activities to objects. or phenomena to be known. Teachers here only play a role as facilitators and mediators to help the student learning process to run to the maximum. In addition, the teacher's role is simply to create problems, stimulate students' thinking and let them discover their ideas and concepts.

Learning for constructivists is a process of constructing knowledge, both personally and socially. This process is included in the active process, while teaching is not only transferring the knowledge given by the teacher to the student, but an activity that allows the student to build their own knowledge. Here teaching is defined as participation with students in forming knowledge, seeking clarity, being critical and seeking clarity. So teaching is a form of self-learning. Constructivism not only looks at the process, but also focuses on the results obtained by learners.

3) The Humanistic

According to Freire (2008), education is a process of human humanization. Ideally, education should help learners to grow and develop into more humane, useful and influential individuals, responsible, proactive and cooperative and able to develop existing potential.

Educators must be able to encourage their learners to achieve success and achieve high achievement when viewed in the context of humanism. In addition, educators must also give recognition for the achievements achieved by learners, even if only in the form of verbal and non-verbal expressions. The appreciation given by the teacher to the learners can sincerely cultivate a sense of success in the participants can also develop a high attitude and motivation to try again in achieving success. However, if 
there are learners who fail, they still need to be rewarded for their enthusiasm and courage to carry out the activity. Here, teachers or educators are required to avoid negative comments and show a dissatisfied attitude to learners who do not succeed or fail. Of course, these negative comments and dissatisfied attitudes can make learners lose self-confidence, feel worthless and can end in despair (Freire, 2008).

The learner-centered approach (humanistic), sees that teaching is focused in a clear direction to help develop the potential of learners optimally and intact. Therefore, an educator is an important element and gives a great influence on the process and learning outcomes, and even determines the success or success of learners in learning.

c. Psychological Foundations

Being a leader requires basic capital to be able to perform managerial functions. Among the main and fundamental managerial functions that a leader needs to have are: Actuating, which is the leader's ability to influence and direct the actions of a person or group in an organization in an effort to utilize human, material, technological and financial resources to achieve organizational goals effectively. This actuating function occupies a fairly important position among the existing managerial functions. When this function is neglected, then a leader no longer functions as a "Puppet", controlled by his subordinates.

There are at least two main components that must exist dominantly in a leader; namely: the ability to motivate subordinates and the ability to manage conflict. Those two competencies are part of the managerial function that a leader must primarily have. The ability to motivate subordinates is a managerial skill that must be mastered by an organizational leader. Because, he is responsible for helping his subordinates perform their tasks effectively and efficiently. It must be understood that a leader is unlikely to influence and motivate subordinates if he does not understand what his needs are. The important role of motivation is to be able to encourage subordinates to do their best and as optimally as possible. By understanding the importance of the role of motivation, a leader can develop the performance and job satisfaction of subordinates.

The leader's ability to manage conflict is based on the reason that subordinates have different psychological characteristics, mindsets and communication styles. The difference has the potential or great opportunity to 
be the cause of conflict between subordinates, which to a lesser extent can disrupt the smoothness or continuity of activities. So the leader's job is to help overcome the problem so that subordinates realize and perform their respective duties, functions and responsibilities.

In leadership theory, three basic approach models are known, namely: (1) trait model, which focuses its subordinates on the personal characteristics of the leader; (2) the behavioral model, which focuses on the actions of the leader; (3) contingency model, which assesses the relationship between the characteristics of the existing situation and the behavior of a leader.

Of these three models, the contingency model is closer to the discussion of the psychological aspects of leadership. The contingency model focuses on the importance of the situation in setting a leadership style appropriate to the problem at hand. According to F. E Fiedler (1967) this leadership style is divided into two parts, namely: leaders who are oriented on people (human relations) and on the task. In the first orientation, leaders get satisfaction when there is a well-established relationship between fellow group members in a job. Subordinates are seen as co-workers (partners) by having a positive relationship. While the second orientation, sees that the leader will be satisfied if able to complete his tasks and subordinates. A harmonious relationship with subordinates is not a priority, because the main priority is the completion of tasks. In other words, ignoring the human relationship with his work. Humanoriented leaders are known by the term trust worthing (emphasizing confidence in subordinates); while task-oriented leaders are called hard workers, because they prefer and prioritize the completion of heavy and challenging tasks.

Differences in psychological characteristics, in organizations can potentially lead to conflicts between individuals. The success of a leader in resolving conflict depends on his ability to identify the causes of the conflict, and choose the appropriate approach in resolving the conflict as well as implement resolution alternatives.

In the dynamics of a pluralistic life with various interests, conflict is a necessity. Therefore, conflicts in the organization (including in educational institutions) should not be avoided, but need to be managed, directed and resolved so as to have a positive contribution to the achievement of organizational goals effectively. 


\section{d. Foundations of Sociology}

In social life, there are three kinds of norms adopted by his followers 1) understand Individualism is based on the theory that human beings are born independent and live independently. Each may do whatever he wishes, as long as it does not disturb the safety of others. The impact of individualism gives rise to a view that prioritizes the interests of the individual over the interests of society, so that a strong impact always wins in competition and only the strong can exist; 2) Collectivism is the opposite of individualization. Understand that collectivism gives an excessive position to society and the individual individually is only as a tool for his society; 3) Integralistic understanding is an understanding that is a combination of individualistic understanding and collectivist understanding. In a society that embraces the integralistic understanding, each member of society is closely related to each other organically and forms a society. Balanced recognition of the rights of individuals and the rights of society. Indonesia is a country formed based on integralistic understanding.

The sociological foundation of education in Indonesia embraces an integralistic understanding derived from the norms of community life: (1) family and gotong royong, togetherness, deliberation for consensus, (2) common prosperity as the goal of community life, (3) the state protects its citizens, (4) harmonious harmonious balance between rights and obligations. Therefore, education in Indonesia not only improves the human quality of the people but also the quality of the structure of society.

From the above description we can describe that educational leadership with a sociological foundation is greatly influenced by the social conditions of society and its institutions, this can be seen from some of the above understandings that in human beings there is a desire to do more than what is in him, both to personal self as well as society in general.

\section{Methods}

This research uses descriptive qualitative research methods. According to Bogdan and Taylor, as quoted by Lexy J. Moleong (2018), qualitative research is a research that produces descriptive data in the form of written or spoken words from people and observed behavior. Meanwhile, descriptive research is a form of research aimed at describing or describing existing phenomena, both natural phenomena and human engineering. The descriptive method was chosen because 
the research carried out was related to ongoing events and with regard to current conditions. The data collection technique used in this study is a literature study. Literature review is a method used to gather data or sources related to the topic raised in a study. Literature studies can be obtained from sharing sources in journals, books, documentation, the internet and libraries. Once the data is collected, the next process is to analyze the data. In providing interpretation of the data obtained, researchers use descriptive methods. Descriptive analysis technique is a research technique that includes the process of collecting data that has been collected and compiled and then analyzed so that clear research data is obtained (Surachmad, 1998). This method is suitable in this study because this study seeks to find a picture of the moral of educational leaders based on religion, philosophy, psychology, and sociology in Indonesia.

\section{Results and Discussion}

The moral of educational leadership is a very important and complex issue because it involves various components and dimensions that are interrelated with each other, covering the context and processes that are constantly evolving, in the context of education, especially in schools. In general, it can be stated that the moral key to educational leadership lies in the person's leadership style. Theoretically, various theories and leadership styles are offered. Among others 1) Bureaucratic: A style characterized by constant attachment to organizational rules. This style assumes that difficulties will be overcome if everyone obeys the rules; 2) Permissive: This leadership style orientation is to make everyone in the group satisfied. Keeping people happy is the rule of the game. This style assumes that when people are satisfied with themselves and others, then the organization will function and thus, the work will be done; 3) Laissez-faire: This style is not leadership at all. This style lets things take their course. The leader only performs the maintenance function; 4) Participatory: This style is used by those who believe that the way to motivate people is to involve them in the decision-making process;

5) Autocratic: This style is characterized by reliance on authority and usually assumes that people will do nothing unless ordered to.

In the world of education, leadership lies with the School Principal. The School Principal is a component who plays an important role in developing the quality of education. The School Principal has a strong role in coordinating, mobilizing, and harmonizing all available educational resources to support the improvement of the quality of education. The leadership of the School Principal is 
one of the factors that can encourage schools to realize their school goals through planned and gradual programs. The principal in setting program objectives is adjusted to the vision and mission of the school, which is the school's fundamentals based on the foundation of education, laws and regulations, future challenges, community values and expectations. Then also the principal paid attention to the real challenges and school outputs in setting school goals.

This is in line with several research results which prove that principal leadership has a positive and significant effect on teacher performance in schools (Imansyah, et al., 2020), teacher job satisfaction (Mawaddah, et al, 2021), improving the quality of education (Ningsih, et al. 2021), and the success of school management (Seriyanti, et al., 2021).

In the Regulation of the Minister of National Education No. 17/2007, there are 5 (five) competencies that must be met by a School Principal in leading an education unit 1) personality competencies, which include: having a noble character, integrity, a strong desire for self-development, openness, self-control and talent and interest in office; 2) managerial competencies, which include: planning, developing organizations, leading schools, managing change, creating a conducive culture/climate, managing teachers and staff, managing facilities, managing relationships, managing students, managing curriculum, managing finances, managing companies, managing units. specialized services, managing information systems, taking advantage of technological advances and monitoring evaluation and reporting; 3) entrepreneurial competencies, which include: creating innovation, working hard, being motivated, never giving up, having entrepreneurial instincts; 4) supervision competencies, which include: planning the supervision program, carrying out supervision and following up on supervision; 5) social competence, which include: cooperating with other parties, participating in social activities and having social sensitivity.

According to Aswarni Sudjud et. al as quoted by Daryanto (2016) stated that the functions of the School Principal are 1) formulating work goals and making school policies; 2) Organizing school work, which includes regulate the division of tasks and authorities, set the executive officer, organize activities (coordinate); 3) Supervision of school activities, including organize the smooth running of activities, directing the implementation of activities, evaluating the implementation of activities, guiding and improving the abilities of the executor.

The term leadership and leader comes from the word 'lead' which contains several meanings that are closely related to the notion of pioneering, guiding, 
encouraging, taking initiative, moving early, preceding, setting an example, moving others, directing others, ordering people and so on. Pamudji (1985) explains that from the word 'lead' is born which means guiding or guiding and the noun leader, namely the person who functions to lead, or the person who guides or guides

According to Islamic teachings other than those mentioned in the letter alImron verse 159 that the concepts and principles of leadership in the Al-Qur'an are mentioned by the term 'Imamah', leader with the term 'Imam'. The Qur'an links leadership with guidance and guidance on truth. A leader must not commit injustice, and never commit injustice at all levels, both injustice in science and deeds and injustice in making decisions and their applications.

Departing from the understanding of the above leadership model analysis, the author will discuss leadership models that are familial in nature. This model, if adjusted to the theoretical leadership model, is closer to a transformational leadership model with a visionary leader's spirit to bring about change for the better. Because in practice, the principal in the institution has a far-reaching vision in order to advance the institution that is led so that the output produced is in accordance with the demands of an increasingly complex era.

Through the kinship system, steps are taken: First, building relationships with superiors, namely the foundation as the person who assigns us to carry out leadership activities or educational activities. So, whatever is done must be based on consultation with the foundation, whatever we take as a policy must involve the foundation for consultations that are carried out in a family manner. Second, communicate in a friendly manner with teachers and employees. A task is done together, if there are obstacles, we try to talk about how we can solve these obstacles together. Third, communicate in a friendly manner with the guardians of students, especially with regard to student problems. Fourth, communicate in a friendly manner with students either through the deputy head of student affairs or BP. Student problems are communicated what problems students face, what are the sources and how to solve them. Because, the student's delinquency is not solely due to the students, but many factors influence it. In essence, leadership in this school emphasizes more on togetherness, namely holding meetings together, deciding together and we are working together".

The professionalism of school principals has a large enough role in advancing educational institutions that are led so that the output produced actually answers the needs of society as an agent of change in responding to the inevitable 
dynamics of life. The responsibility of the principal as visionary leadership is manifested by giving concern for the development of teacher performance from time to time. Serious attention to this matter will provide significant implications in improving the quality of teachers as expected.

The application of moral leadership in an institution, especially in education, becomes a barometer for an institution to achieve success or not, because each leadership model that is applied has its own implications for the educational process carried out and the output produced. Conceptually, there are three leadership models, namely transactional, transformational and visionary leadership models. Another opinion states that there are four models of leadership, namely, autocratic, paternalistic, participatory and democratic.

In practice, the principal has a far-reaching vision to develop an institution that is led by mobilizing all elements to form a complementary unit. Leadership and power have an inseparable attachment. Because to become a leader is not only based on liking each other, but many factors. A moral leader should have several criteria depending on the point of view or approach used, whether it is his personality, skills, talents, traits, or authority, which will greatly influence the theory and leadership style that will be applied. The main secret of leadership is having a moral priesthood and trustworthiness because the greatest strength of a leader is not from his power, not his intelligence, but from his personal strength. A true leader always works hard to improve himself before he is busy fixing others. Leader is not just a title or position given from outside but something that grows and develops from within a person. Leadership is born from an internal process (leadership from the inside out).

\section{Conclusion}

Based on analysis data and discussion above, it can be concluded that 1) according to the Religion, moral of education leaders is not power, not a position and authority to be proud of. Leadership is not merchandise that can be bought and sold. The essence of leadership in the view of Islam is a mandate that must be carried out properly and accounted for not only in the world but also before Allah in the afterlife. Leadership that is not carried out professionally and proportionally is betrayal of Allah and His Messenger; 2) according to the Philosophy, leaders can do a job or oppression based on a deep way of thinking so that the negative and positive sides are really taken into account. When it is related to decision making, the leader in making decisions must use the right way of thinking, so as 
to avoid wrong decisions; 3) according to the Psychology, the leadership style of moraled leaders influences the process of living his daily life, because it is a basic human nature from birth to death, so that his leadership style is influenced by factors from within himself, while external factors are influenced by the knowledge he learns, organizational experiences, literature and theory in real life; and 4) according to the Sociology, a moral of educational leadership is much influenced by the social conditions of society and its institutions, this can be seen from some of the above understandings that in humans there is a desire to do greater than what is in themselves, be it for oneself.

\section{References}

Badan Pengembangan dan Pembinaan Bahasa Kementerian Pendidikan dan Kebudayaan. (2018). Kamus Besar Bahasa Indonesia [Indonesia Dictionary]. Jakarta: Balai Pustaka.

Barnadib, S. I. (2000). Pengantar Ilmu Pendidikan Sistematis [Introduction to Systematic Education]. Yogyakarta: Andi Offset.

Bennis, W. (2021). On becoming a leader. Perseus Books Group.

Boardman, C. W. (1977). Democratic Supervision in Secondary School. Boston: Houghton Mifflin Company.

Covey, S. R. (1997). Kepemimpinan Berprinsip [Principled Leadership]. Jakarta: Binapura Aksara.

Daryanto. (2016). Media Pembelajaran [Learning Media]. Yogyakarta: Gava Media.

Fiedler, F. E. (1967). A Theory of Leardership Effectiveness. New York: McGraw-Hill.

Freire, Paulo. (2008). Pendidikan Masyarakat Kota [City Community Education]. Yogyakarta: LKIS.

Imansyah, M.; Yasir Arafat dan Dessy Wardiah. (2020). Pengaruh Kepemimpinan Kepala Sekolah dan Partisipasi Komite Sekolah terhadap Kinerja Guru [The Influence of Principal Leadership and School Committee Participation on Teacher Performance]. JMKSP (Jurnal Manajemen, Kepemimpinan, dan Supervisi Pendidikan), 5(2), 135-143. 
Kartono, Kartini. (2009). Pemimpin dan Kepemimpinan: Apakah Pemimpin Abnormal itu? [Leaders and Leadership: What are Abnormal Leaders?] Jakarta: PT. Raja Grafindo Persada.

Kneller, G. F. (1971). Introduction to the Philosophy of Education. New York: John.

Mawaddah., Harapan, E., \& Kesumawati, N. (2021). Pengaruh Kepemimpinan Kepala Sekolah dan Ketersediaan Sarana dan Prasarana terhadap Kepuasan Kerja Guru [The Influence of Principal Leadership and Availability of Facilities and Infrastructure on Teacher Job Satisfaction]. JMKSP (Jurnal Manajemen, Kepemimpinan, dan Supervisi Pendidikan), 6(1), 100-111.

Moleong, L. J. (2018). Metodologi Penelitian Kualitatif [Qualitative Research Methodology]. Bandung: PT Remaja Rosdakarya.

Ningsih, K. D., Harapan, E., \& Destiniar. (2021). Pengaruh Komite Sekolah dan Kepemimpinan Kepala Sekolah terhadap Peningkatan Mutu Pendidikan [The Influence of School Committees and Principal Leadership on Improving the Quality of Education]. JMKSP (Jurnal Manajemen, Kepemimpinan, dan Supervisi Pendidikan), 6(1), 1-14.

Nugroho, I. (2016). Kepemimpinan Perpaduan Iman, Ilmu dan Akhlak [Leadership Combination of Faith, Science and Morals]. Yogyakarta: Pustaka Pelajar.

Pamudji, S. (1985). Kerja Sama Antar Daerah Dalam Rangka Pembinaan Wilayah: Suatu Tinjauan Dari Administrasi Negara [Inter-Regional Cooperation in the Context of Regional Development: An Overview From State Administration]. Jakarta: Institut Ilmu Pemerintahan.

Raharjo, S. T. (2006). Analisis Pengaruh Gaya Kepemimpinan Terhadap Kepuasan Kerja, Komitmen Organisasi dan Kinerja Karyawan (Studi Empiris pada Departemen Agama Kabupaten Kendal dan Departemen Agama Kota Semarang) [Analysis of the Influence of Leadership Style on Job Satisfaction, Organizational Commitment and Employee Performance (Empirical Study at the Department of Religion of Kendal Regency and the Department of Religion of Semarang City)]. Jurnal Studi Manajemen dan Organisasi. 3(2), 69-81. 
Rivai. (2003). Kepemimpinan Pendidikan [Educational Leadership]. Jakarta: Cahaya Ilmu.

Robbins, S. P. (1983). Esentials of Organizational Behavior. Prince-Hall.

Sauri, S. (2019). Manajemen Pendidikan Berbasis Nilai [Value-Based Education Management]. Bandung: Revika Press.

Sauri, Sofyan. (2019). Pendidikan Karakter Dalam Perspektif Islam [Character Education in Islamic Perspective]. Bandung: Rizki Press.

Seriyanti, N., Ahmad, S., \& Destiniar. (2021). Pengaruh Kepemimpinan Kepala

Sekolah dan Peran Komite Sekolah terhadap Keberhasilan Manajemen Berbasis Sekolah [The Influence of Principal Leadership and the Role of School Committees on the Success of School-Based Management]. JMKSP (Jurnal Manajemen, Kepemimpinan, dan Supervisi Pendidikan), 6(1), 1533.

Stogdill. (1990). Hand Book of Leadership: A Survey of Theory and Research. Third Edition. New York: Free Press.

Sukamto. (1999). Kepemimpinan Kiai dalam Pesantren [Kiai Leadership in Islamic Boarding School]. Jakarta: LP3ES.

Surachmad, W. (1998). Pengantar Penelitian Ilmiah: Dasar Metode Tehnik [Introduction to Scientific Research: Fundamentals of Technical Methods]. Bandung: Tarsito.

Terry, G. R. (2003). Prinsip-Prinsip Manajemen [Management Principles]. Jakarta: Bumi Aksara.

Usman, H. (2014). Manajemen Teori, Praktik, dan Riset Pendidikan [Management Theory, Practice and Educational Research]. Jakarta: Bumi Aksara. 